\title{
Aerobic carboxydotrophy under extremely haloalkaline conditions in Alkalispirillum/ Alkalilimnicola strains isolated from soda lakes
}

\begin{abstract}
Correspondence
Dimitry Yu. Sorokin

soroc@inmi.host.ru

d.sorokin@tudelft.nl
\end{abstract}

Received 12 August 2009

Revised 6 November 2009

Accepted 2 December 2009

\author{
Dimitry Yu. Sorokin, ${ }^{1,2}$ Tatjana P. Tourova, ${ }^{1}$ Olga L. Kovaleva, ${ }^{3}$ \\ J. Gijs Kuenen ${ }^{2}$ and Gerard Muyzer ${ }^{2}$
${ }^{1}$ Winogradsky Institute of Microbiology, Russian Academy of Sciences, Prospect 60-let Octyabrya 7/2, 117811 Moscow, Russia
${ }^{2}$ Department of Biotechnology, Delft University of Technology, Delft, The Netherlands \\ ${ }^{3}$ Faculty of Biology, Department of Microbiology, Moscow State University, Moscow, Russia
}

\begin{abstract}
Aerobic enrichments from soda lake sediments with $\mathrm{CO}$ as the only substrate resulted in the isolation of five bacterial strains capable of autotrophic growth with $\mathrm{CO}$ at extremely high $\mathrm{pH}$ and salinity. The strains belonged to the Alkalispirillum/Alkalilimnicola cluster in the Gammaproteobacteria, where the ability to oxidize $\mathrm{CO}$, but not growth with $\mathrm{CO}$, has been demonstrated previously. The growth with $\mathrm{CO}$ was possible only at an oxygen concentration below $5 \%$ and $\mathrm{CO}$ concentration below $20 \%$ in the gas phase. The isolates were also capable of growth with formate but not with $\mathrm{H}_{2}$. The carboxydotrophic growth occurred within a narrow $\mathrm{pH}$ range from 8 to 10.5 (optimum at 9.5) and a broad salt concentration from 0.3 to $3.5 \mathrm{M}$ total Na$^{+}$ (optimum at $1.0 \mathrm{M}$ ). Cells grown on $\mathrm{CO}$ had high respiration activity with $\mathrm{CO}$ and formate, while the cells grown on formate actively oxidized formate alone. In CO-grown cells, CO-

dehydrogenase $(\mathrm{CODH})$ activity was detectable both in soluble and membrane fractions, while the NAD-independent formate dehydrogenase $(\mathrm{FDH})$ resided solely in membranes. The results of total protein profiling and the failure to detect $\mathrm{CODH}$ with conventional primers for the cox $\mathrm{L}$ gene indicated that the $\mathrm{CO}$-oxidizing enzyme in haloalkaliphilic isolates might differ from the classical aerobic $\mathrm{CODH}$ complex. A single cbbL gene encoding the RuBisCO large subunit was detected in all strains, suggesting the presence of the Calvin cycle of inorganic carbon fixation. Overall, these results demonstrated the possibility of aerobic carboxydotrophy under extremely haloalkaline conditions.
\end{abstract}

\section{INTRODUCTION}

$\mathrm{CO}$ is a low-potential and very toxic electron donor which can be utilized as an energy source for aerobic lithoautotrophic growth only by a few highly specialized bacteria that possess a CO-insensitive respiratory chain. Such bacteria are known as carboxydotrophs (Meyer et al., 1990; Mörsdorf et al., 1992). Recent work by Hardy \& King (2001), Dunfield \& King (2004) and Tolli et al. (2006) has shown that the actual diversity of carboxydotrophic

\footnotetext{
Abbreviations: $\mathrm{CODH}$, CO-dehydrogenase; FDH, formate dehydrogenase; SOR, sulfide-quinone reductase.

The GenBank/EMBL/DDBJ accession numbers for the 16S rRNA gene and $\mathrm{CbbL}$ gene sequences of the ACO isolates are FJ976677FJ976681 and FJ959400-FJ959404, respectively.

Two supplementary figures, showing cell morphology of the CO-utilizing isolates from soda lakes grown with $\mathrm{CO}$ at $\mathrm{pH} 10$, and reduced minus air-oxidized cytochrome spectra of strain ACO1 grown with $\mathrm{CO}$, are available with the online version of this paper.
}

bacteria able to proliferate at low CO concentrations is substantially broader than previously anticipated. Recently, a large diversity of the $[\mathrm{Mo}-\mathrm{Cu}] \mathrm{CO}$-dehydrogenase $(\mathrm{CODH})$, a key enzyme of the CO-oxidizing system in aerobic carboxydobacteria, has been detected in various habitats by two degenerate primer pairs that specifically target the coxL gene, encoding the large catalytic subunit of CODH (King, 2003; Dunfield \& King, 2004; King \& Weber, 2007). This has substantially broadened the diversity of bacteria (both within the Proteobacteria and the Firmicutes) capable of utilizing $\mathrm{CO}$ as an electron donor compared with those previously recognized on the basis of cultivation at high $\mathrm{CO}$ concentrations. In contrast to carboxydotrophs, actually growing on $\mathrm{CO}$, many of the latter can only oxidize $\mathrm{CO}$ without autotrophic growth and are called 'carboxydovores'. Most probably, they belong to the lithoheterotrophs.

A very recent example points to the possibility of aerobic CO oxidation under extremely haloalkaline conditions. 
The genome sequence of a haloalkaliphilic gammaproteobacterium, Alkalilimnicola ehrlichii, from the haloalkaline Mono Lake, CA, USA, indicated the presence of a putative coxL gene, which was confirmed by PCR. Further physiological testing revealed the potential of this bacterium, as well as the type strain Alkalilimnicola halodurans and its closest relative Alkalispirillum mobilis, to aerobically consume $\mathrm{CO}$ at various concentrations, but without autotrophic growth (Hoeft et al., 2007). The absence of autotrophic growth in this case cannot be explained, as Alkalilimnicola can grow lithoautotrophically with other electron donors and has a complete set of RuBisCO genes. Accordingly, although the potential for aerobic CO oxidation under highly alkaline conditions has already been proven, the possibility of a carboxydotrophic mode of growth under these doubly extreme conditions remained unclear.

In this paper, we describe a group of Gammaproteobacteria that is capable of growth with $\mathrm{CO}$ under extremely haloalkaline conditions. All five carboxydotrophic isolates obtained from soda lake sediments belonged to the Alkalispirillum/Alkalilimnicola group.

\section{METHODS}

Samples. Top 5-8 cm sediment samples were collected from 10 hypersaline soda lakes in Kulunda Steppe (Altai, south-west Siberia, Russia) in 2008, with the $\mathrm{pH}$ and salinity of the brines ranging from 10.0 to 10.6 and from 60 to $300 \mathrm{~g} \mathrm{l}^{-1}$, respectively. In addition, sediments from eight hypersaline alkaline lakes in Wadi Natrun (Lybian desert, Egypt; collected in 2000) with a pH and salinity ranging from 9.0 to 10.1 and from 180 to $300 \mathrm{~g} \mathrm{l}^{-1}$, respectively, were used. Before use, the samples were kept at $4{ }^{\circ} \mathrm{C}$. The individual samples from each area were pooled together in equal proportion to make two mixed-sediment inocula.

Enrichment, isolation and cultivation of pure cultures. A purely mineral medium based on sodium carbonate/bicarbonate strongly buffered at $\mathrm{pH} 10$ and with a total $\mathrm{Na}^{+}$content from 0.6 to $4 \mathrm{M}$ (Sorokin et al., 2006a) was employed for enrichment and routine cultivation. Ammonium (4 mM) served as the nitrogen source. The concentration of Mo in the trace metal solution (Pfennig \& Lippert, 1966) was increased to $40 \mu \mathrm{g} \mathrm{l}^{-1}$. Routine incubations with CO as the electron donor were performed in $100 \mathrm{ml}$ serum bottles capped with black butyl rubber and containing $50 \mathrm{ml}$ mineral liquid medium. The gas phase contained $2-20 \% \mathrm{O}_{2}$ and $2-50 \% \mathrm{CO}$, with the balance argon. The enrichment was inoculated with the fine fraction of the sediments $(2 \%, \mathrm{v} / \mathrm{v})$ after removal of coarse sandy material by lowspeed centrifugation. The incubation was performed at $30{ }^{\circ} \mathrm{C}$ statically. The culture was monitored by $\mathrm{CO}$ analysis in $0.1 \mathrm{ml}$ gasphase samples. When more than $50 \%$ of the CO had been consumed, the enrichments (without the residual sediment) were subcultured several times at 1:100 dilutions and then serially diluted in $20 \mathrm{ml}$ tubes with $5 \mathrm{ml}$ liquid medium of the same composition placed into closed 3.51 jars with the same $\mathrm{CO} / \mathrm{O}_{2}$ content used in the positive enrichments. The highest positive dilutions were also subjected to a second serial dilution or directly plated onto solid medium prepared by $1: 1$ mixing of the liquid soda base with $4 \%$ washed agar at $50{ }^{\circ} \mathrm{C}$. The plates were incubated under the same conditions as the serially diluted tubes. After a month of incubation, the dominant colony types were isolated into $5 \mathrm{ml}$ liquid medium in tubes and grown in closed jars. The colonies which resulted in positive liquid cultures (determined by turbidity) were subjected to another round of solidmedium purification, and eventually, after confirmation of their purity by colony morphology, microscopy and denaturing gradient gel electrophoresis (DGGE), were characterized further.

The dynamics of growth were studied using $200 \mathrm{ml}$ cultures in 11 butyl rubber-capped bottles with a gas phase containing 10-20\% CO and $5 \% \mathrm{O}_{2}$. The bottles were incubated at $30{ }^{\circ} \mathrm{C}$ with gentle shaking at 100 r.p.m. When $\mathrm{CO}$ and $\mathrm{O}_{2}$ were depleted, the gas phase was replaced. The biomass growth was routinely monitored by measuring $\mathrm{OD}_{590}$ and cell protein (Lowry et al., 1951) after centrifugation of 1$2 \mathrm{ml}$ culture. A large quantity of cells for enzymic analysis was produced in 201 bottles with 51 medium and several replacements of the gas phase during growth. The influence of $\mathrm{pH}$ on growth and activity (see below) with $\mathrm{CO}$ in pure cultures was investigated in media containing $0.6 \mathrm{M}$ total $\mathrm{Na}^{+}$either as $\mathrm{NaCl}(0.1 \mathrm{M}$ HEPES, pH $<8.5$ ) or as sodium carbonate/bicarbonate $(\mathrm{pH} 8.5-11.0)$. The effect of sodium on growth and activity was examined at $\mathrm{pH} 10$ using a carbonate/bicarbonate buffer system containing 0.1-4.0 $\mathrm{M}$ total $\mathrm{Na}^{+}$.

Activity of washed cells. Cultures were grown under defined conditions and the cells were harvested in late exponential phase by centrifugation, washed and resuspended at $20 \mathrm{mg}$ protein $\mathrm{ml}^{-1}$ in sodium carbonate buffer, $0.6 \mathrm{M} \mathrm{Na}^{+}, \mathrm{pH} 10$. Respiration rates with different electron donors were measured in a $4 \mathrm{ml}$ final volume in the same buffer at a cell density of $0.1 \mathrm{mg}$ protein $\mathrm{ml}^{-1}$ using an oxygen electrode (Yellow Springs Instruments). $\mathrm{CO}$ and $\mathrm{H}_{2}$ were introduced as saturated solutions in the same buffer maintained at $30{ }^{\circ} \mathrm{C}$ at a final concentration of $0.2 \mathrm{mM}$; sulfide, formate and acetate were used at a final concentration of $0.1 \mathrm{mM}$. In some cases, the CO-utilizing activity of washed cells $\left(0.5 \mathrm{mg}\right.$ protein $\left.\mathrm{ml}^{-1}\right)$ under different conditions was measured directly by analysing $\mathrm{CO}$ consumption from the gas phase.

Enzymic activities. Cells were disrupted by sonication and the extracts were separated into soluble and membrane fractions by ultracentrifugation at $144000 \mathrm{~g}$ for $2 \mathrm{~h}$. CODH and formate dehydrogenase $(\mathrm{FDH})$ activities in the cell fractions were assayed spectrophotometrically according to Lorite et al. (2000) using a combination of phenazine methosulfate (PMS) and nitrotetrazolium blue (NTB) as artificial electron acceptors. The same method was employed for the in-gel activity staining. Briefly, native $8 \%$ polyacrylamide gels were cut into two parts after completion. One part was stained for protein standards and the other part was washed and then incubated anaerobically in closed jars for $20 \mathrm{~min}$ in $0.1 \mathrm{M}$ HEPES, pH 8/0.3 M NaCl/PMS + NTB in the presence of either $20 \%$ $\mathrm{CO}$ in the gas phase $(\mathrm{CODH})$ or $20 \mathrm{mM}$ formate (FDH). The membrane fraction was run in the presence of $0.1 \%$ of the detergent $\beta$-D-dodecyl maltoside. Protein electrophoresis under denaturing conditions was done according to Laemmli (1970) using 5-20\% gradient gels. Sulfide-quinone reductase (SQR) activity in membranes was measured at $\mathrm{pH} 9$ with $0.2 \mathrm{mM}$ each of sulfide and decylubiquinone. The $1 \mathrm{ml}$ reaction mixture was incubated anaerobically in $1.5 \mathrm{ml} \mathrm{HPLC}$ screw-capped flasks for $30 \mathrm{~min}$, and the disappearance of sulfide was analysed in $0.1 \mathrm{ml}$ samples taken every $5 \mathrm{~min}$. In controls, decyl-ubiquinone was omitted. Cytochrome $c$ oxidase activity in membranes was measured spectrophotometrically at pH 8 using tetramethyl-p-phenylenediamine (TMPD) (1 mM) as substrate.

Analyses. $\mathrm{CO}$ and $\mathrm{O}_{2}$ concentrations in the gas phase were measured by a gas chromatograph (Varian CP 3800) equipped with a MolSieve capillary column $\left(1.2 \mathrm{~m} \times 1 \mathrm{~mm} ; 13 \times 80 / 100\right.$ mesh; $\left.50{ }^{\circ} \mathrm{C}\right)$ and a thermal conductivity detector (TCD) $\left(200{ }^{\circ} \mathrm{C}\right)$, with $\mathrm{N}_{2}$ as a carrier gas $(2 \mathrm{ml} \mathrm{min}-1)$. Formate was analysed by anionic chromatography HPLC [column HPX-87-H (Bio-Rad) at $60{ }^{\circ} \mathrm{C}$; UV/IR detector;

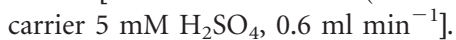


The cytochrome composition in cell fractions was analysed spectroscopically using a UV/visible diode array HP 8453 spectrophotometer. Formate $(1 \mathrm{mM})$ and $\mathrm{CO}(0.4 \mathrm{mM})$ were tested as natural reductants, and ascorbate $(1 \mathrm{mM})$ and dithionite (a few crystals) as high- and low-potential artificial reductants, respectively.

Phase-contrast microphotographs were obtained using a Zeiss Axioplan Imaging 2 microscope. For electron microscopy, the cells were fixed in glutaraldehyde (final concentration $3 \%$, v/v) in $0.5 \mathrm{M}$ $\mathrm{NaCl}$, and after removal of the fixative stained with $2 \%(\mathrm{w} / \mathrm{v})$ uranyl acetate, and cells were imaged with a Jeol-100 electron microscope.

DNA analysis. Genomic DNA for total analysis was extracted by the phenol/chloroform method (Marmur, 1961). G + C content determination and DNA-DNA hybridization were performed by the thermal denaturation/reassociation technique (Marmur \& Doty, 1962; De Ley et al., 1970) using Escherichia coli as a standard. Genomic DNA for PCR was extracted from the cell pellet using the UltraClean Microbial DNA Isolation kit (Mo Bio Laboratories), following the manufacturer's instructions. The 16S rRNA gene was amplified using general bacterial primers GM3(f) and GM4(r) (Schäfer \& Muyzer, 2001). To amplify the $c b b L$ gene fragment (800 bp), encoding the RuBisCO large subunit form I, a specially designed primer pair and protocol were used (Spiridonova et al., 2004). Detection of the coxL gene, encoding the catalytic subunit of $\mathrm{CODH}$, was performed according to Dunfield \& King (2004) with primers OMPf-O/Br (type I) and $\mathrm{BMSr}-\mathrm{O} / \mathrm{Br}$ (putative). Genomic DNA from Oligotropha carboxydovorans was used as a positive control. The PCR products were purified from agarose using the QIAquick Gel Extraction kit (Qiagen). Phylogenetic trees were reconstructed using the TREECON W package (Van de Peer \& De Wachter, 1994). The sequences obtained in this study were determined commercially (Macrogen, Korea).

\section{RESULTS}

\section{Enrichment, isolation and identification of pure cultures}

Primary enrichments from soda lake sediments at $\mathrm{pH} 10$ using variable salt, $\mathrm{CO}$ and $\mathrm{O}_{2}$ concentrations resulted in five positive cultures in which at least $50 \%$ of the $\mathrm{CO}$ was consumed within a month of incubation. In general, this demonstrated that aerobic $\mathrm{CO}$ consumption was possible in soda lake sediments at $\mathrm{CO}$ and $\mathrm{O}_{2}$ contents in the gas phase below 20 and $5 \%$, respectively, and an $\mathrm{Na}^{+}$ concentration below $2 \mathrm{M}$. Further combinations of dilution series and plating eventually allowed the isolation of a single bacterial pure culture from each of the five enrichments that was capable of growth with $\mathrm{CO}$ on purely mineral medium (Table 1). The bacteria were represented by motile vibrioshaped cells of variable length (Supplementary Fig. S1). When $\mathrm{CO}$ was replaced with acetate, all strains accumulated a large amount of polyhydroxyalkanoates (PHA) (confirmed by Nile blue staining).

$16 \mathrm{~S}$ rRNA gene sequence analysis placed the ACO isolates in the Alkalispirillum (four strains)/Alkalilimnicola (one strain) cluster in the family Ectothiorhodospiraceae of the Gammaproteobacteria (Fig. 1a), where the potential to consume (but not to grow with) $\mathrm{CO}$ has been demonstrated in Alkalilimnicola ehrlichii (Hoeft et al., 2007). It may be that low oxygen and CO concentrations are critical to achieve carboxydotrophic growth in this group of haloalkaliphiles. Our previous work under variable denitrifying conditions also resulted in a selection of several Alkalispirillum/Alkalilimnicola members from soda lake sediments (Sorokin et al., 2006b). Two out of three of those earlier isolates, namely Alkalispirillum sp. AGDZ and Alkalispirillum sp. ALPs2, turned out to be able to grow with $\mathrm{CO}\left(20 \% \mathrm{CO} / 5 \% \mathrm{O}_{2}\right)$. On the other hand, an $\mathrm{H}_{2}-$ utilizing strain, Alkalimnicola sp. AHN1, from the same habitat neither consumed nor grew on CO. From this, we may conclude that the carboxydotrophy under microoxic conditions is an inherent property of the genus Alkalispirillum (six confirmed isolates). Whether this also applies to the genus Alkalilimnicola (Alkalilimnicola ehrlichii and one of the ACO isolates) remains to be seen.

DNA-DNA hybridization data were also consistent with the 16S rRNA gene-based clustering of the ACO isolates. Strains ACO1, 2, 3 and 4 had DNA similarity above $65 \%$ between each other, with the type strain Alkalispirillum mobile, and with the previously described denitrifying isolates Alkalispirillum AGDZ and ALPs2, while strain ALCO5 showed only $30-35 \%$ similarity with the Alkalispirillum ACO strains and obviously belonged to the genus Alkalilimnicola.

Table 1. Isolation of pure cultures of haloalkaliphilic carboxydotrophs from soda lakes

\begin{tabular}{|c|c|c|c|c|c|c|c|}
\hline Source & $\begin{array}{c}\text { CO concn } \\
(\%)\end{array}$ & $\begin{array}{c}\mathrm{O}_{2} \text { concn } \\
(\%)\end{array}$ & $\begin{array}{c}\mathrm{Na}^{+} \text {concn } \\
(\mathrm{M})\end{array}$ & Strain & Cell morphology & $\begin{array}{c}\text { DNA G + C } \\
(\mathrm{mol} \%)\end{array}$ & $\begin{array}{c}\text { NCCB } \dagger \\
\text { no. }\end{array}$ \\
\hline \multirow[t]{3}{*}{ Kulunda steppe } & 20 & 5 & 0.6 & $\mathrm{ACO} 1$ & Bean-shaped rod & 65.6 & 100201 \\
\hline & 10 & 5 & 2.0 & $\mathrm{ACO} 2$ & Short vibrio & 66.0 & 100202 \\
\hline & 10 & 5 & 0.6 & $\mathrm{ACO} 4$ & Long vibrio & 65.5 & 100203 \\
\hline Wadi Natrun & 10 & 5 & 2.0 & $\mathrm{ACO} 3$ & Short vibrio & 65.8 & 100205 \\
\hline
\end{tabular}

${ }^{*}$ Negative results were obtained when the following concentrations were used: $\mathrm{CO}>20 \% ; \mathrm{O}_{2}>5 \% ; \mathrm{Na}^{+}>2 \mathrm{M}$.

$\uparrow$ Netherlands Culture Collection of Bacteria. 
(a)



(b)

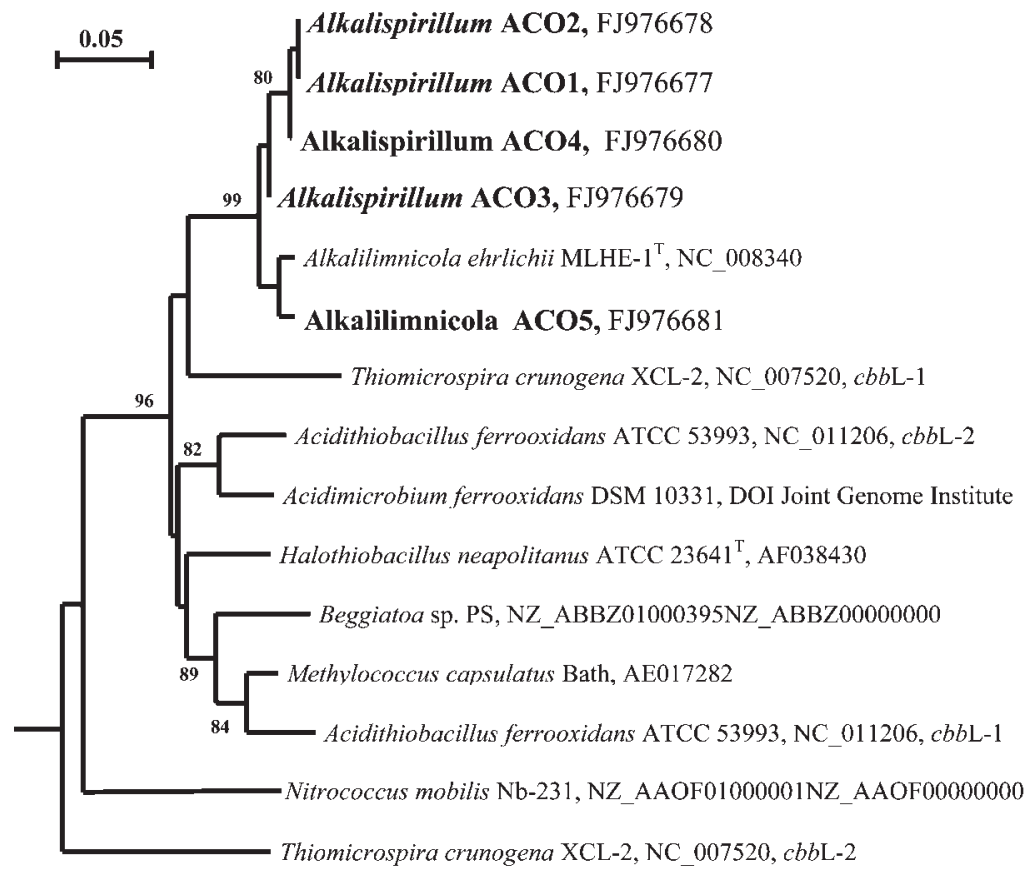

Fig. 1. Phylogenetic position of the COutilizing isolates based on sequence analysis of the 16S rRNA gene (a) and the cbbl gene (b) (amino acid sequences translated from the DNA sequences). The phylogenetic trees were reconstructed from evolutionary distances by using the neighbour-joining method. Bars, number of substitutions (\%); the numbers at the nodes show bootstrap values above $70 \%$ obtained from 1000 resamplings. Strains discussed in this study are in bold type.
Analysis of the $c b b L$ gene, encoding the form I large subunit of RuBisCO (the key enzyme of the Calvin-Benson cycle of autotrophic $\mathrm{CO}_{2}$ assimilation) showed that it was universally present in the CO-utilizing isolates. The phylogeny of this gene was consistent with the clustering on the basis of the $16 \mathrm{~S}$ rRNA gene (Fig. 1b). This gene has also been detected in the genome of Alkalilimnicola ehrlichii (Hoeft et al., 2007) and in the denitrifying Alkalispirillum/Alkalilimnicola isolates from soda lakes (Tourova et al., 2007).

\section{Growth physiology}

Strain ACO3 was able to grow with $\mathrm{CO}$ at concentrations up to $10 \%$ in the gas phase; ACO2, 4 and 5 up to $20 \%$; and 
ACO1 up to $30 \%$ after a gradual adaptation. The COgrowing cultures were inhibited by oxygen concentrations above $5 \%$ in the gas phase at the beginning of growth and tolerated up to $10 \%$ when the cultures reached sufficient density (above $20 \mathrm{mg}$ cell protein $\mathrm{l}^{-1}$ ). Despite being active denitrifiers (with acetate), the ACO strains were unable to use $\mathrm{CO}$ as electron donor under denitrifying conditions at concentrations of 1-20\% (with nitrate or $\mathrm{N}_{2} \mathrm{O}$ as acceptors). Furthermore, in contrast to most of the known aerobic carboxydotrophs (King \& Weber, 2007), and closely related Alkalilimnicola ehrlichii (Hoeft et al., 2007) and Alkalilimnicola AHN1 (Sorokin et al., 2006b), the ACO strains failed to grow with $\mathrm{H}_{2}$, under either microoxic or denitrifying conditions. On the other hand, all of them grew aerobically with formate as the sole carbon and energy source at full oxygen (atmospheric air, 20\% $\mathrm{O}_{2}$ ) with growth rates similar to growth on $\mathrm{CO}$. The maximum experimental growth rate for growth on $\mathrm{CO}$ and formate in different ACO strains varied from 0.015 to $0.022 \mathrm{~h}^{-1}$; heterotrophic growth with acetate was 10 times faster, with rates from 0.15 to $0.20 \mathrm{~h}^{-1}$. The maximal experimental growth yields with $\mathrm{CO}$, formate and acetate determined for strain $\mathrm{ACO} 1$ at $\mathrm{pH} 10$ and $0.6 \mathrm{M}$ total $\mathrm{Na}^{+}$were $1.05-1.4$ $\mathrm{mg}$ cell protein $\mathrm{mmol}^{-1}$ (five different experiments), 1.2 $\mathrm{mg}$ cell protein $\mathrm{mmol}^{-1}$ (single experiment) and 10.0-10.5 $\mathrm{mg}$ cell protein $\mathrm{mmol}^{-1}$ (two experiments), respectively. With $\mathrm{CO}$ alone, the $\mathrm{CO}$ consumption was parallel to biomass growth (Fig. 2a). Under mixotrophic conditions with $\mathrm{CO}$ and acetate, a much higher biomass was reached, but the growth rate resembled that of carboxydotrophic cultures, indicating suppression of acetate-dependent energy metabolism by CO (Fig. 2b).

\section{Influence of pH and salinity on growth and activity}

With respect to their $\mathrm{pH}$ response, the ACO isolates belonged to the obligate alkaliphiles. Autotrophic growth with $\mathrm{CO}$ was possible within a $\mathrm{pH}$ range from 8.0 to 10.5 , with an optimum at around 9.5 (Fig. 3a). The respiration of washed cells grown at $\mathrm{pH} 10$ with $\mathrm{CO}$ had a much broader $\mathrm{pH}$ range and was still active up to $\mathrm{pH} 11.7$, which is the highest $\mathrm{pH}$ for activity among the known haloalkaliphilic chemolithoautotrophs (Sorokin \& Kuenen, 2005). Sulfide oxidation by the cells grown with CO (see below) and acetate oxidation by heterotrophically grown cells of strain ACO1 also had a highly alkaline $\mathrm{pH}$ optimum at 9.510.0 , but these activities were definitely less alkalitolerant


strains grew immediately with $\mathrm{CO}$ in soda brines at a salt content of up to $2.5 \mathrm{M}$ total $\mathrm{Na}^{+}$, and after adaptation at $2 \mathrm{M}$ at up to $3.5 \mathrm{M} \mathrm{Na}^{+}$(Fig. 3b). The same salt limit was observed for heterotrophic growth with acetate, except that adaptation was not necessary and that two strains (ACO3 and 4) tolerated salt-saturating conditions $\left(4 \mathrm{M} \mathrm{Na}^{+}\right)$. Concerning their salinity optimum, however, the ACO strains definitely belonged to a moderately salt-tolerant type, with growth and activity maxima around $1 \mathrm{M}$ total $\mathrm{Na}^{+}$.
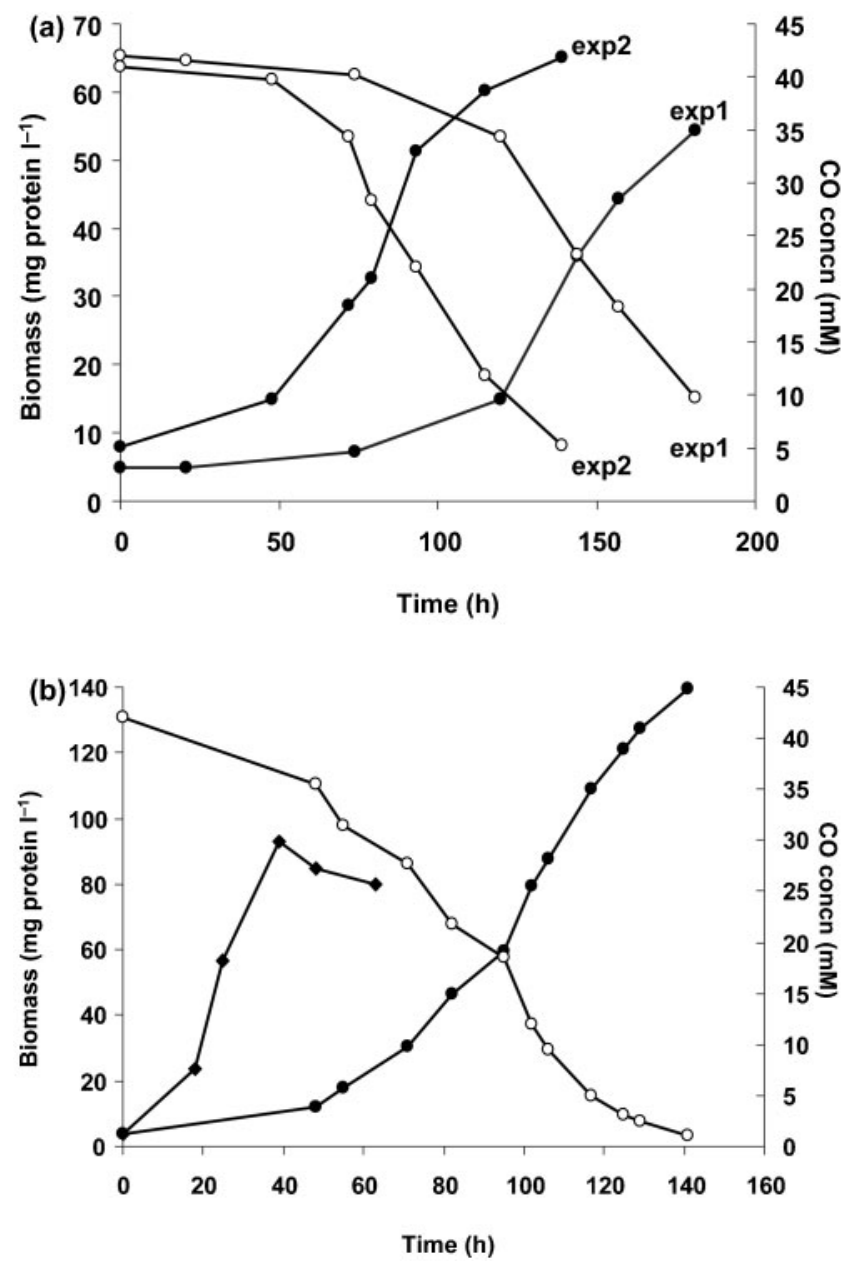

Fig. 2. Growth dynamics of strain ACO1 under lithoautotrophic conditions with $20 \%$ CO (a) (results of two independent experiments) and (b) in mixotrophic culture (5 mM acetate $+20 \%$ $\mathrm{CO})$ in comparison with heterotrophic culture on acetate $(5 \mathrm{mM})$. Symbols: 0 , biomass growth in carboxydotrophic and mixotrophic cultures; biomass growth in heterotrophic culture with acetate; $\mathrm{O}, \mathrm{CO}$ consumption.

\section{Metabolic activity of resting cells}

The CO-oxidizing capacity was fully expressed only when CO was used as the sole substrate and was inhibited in cells grown with either formate or acetate (Fig. 4). Acetate metabolism was also repressed in the presence of $\mathrm{CO}$, which corresponded to the results of growth experiments. On the other hand, the COgrown cells respired formate with the same activity as $\mathrm{CO}$, although the activity was $40 \%$ lower than in cells grown with formate. While the same phenomenon has been shown in the neutrophilic carboxydotroph Oligotropha carboxydovorans (formerly known as Pseudomonas) (Meyer \& Schlegel, 1978), the formate oxidation activity induced in CO-grown cells of Oligotropha was 10 times lower than the CO-oxidizing activity. Furthermore, the cells of all ACO strains grown with either CO or formate also exhibited a significant sulfide-dependent 

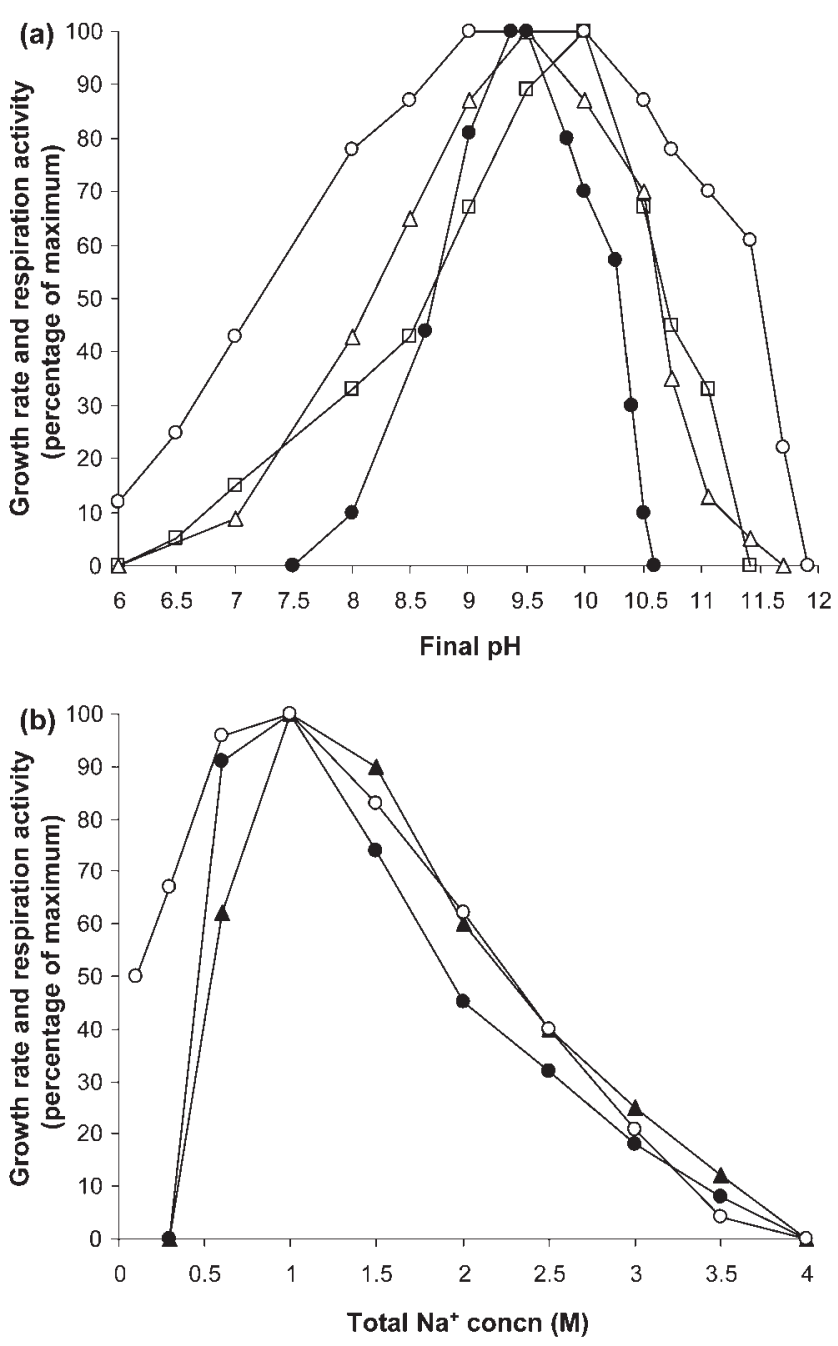

Fig. 3. Influence of $\mathrm{pH}$ at $0.6 \mathrm{M}$ total $\mathrm{Na}^{+}$(a) and sodium carbonate concentration at $\mathrm{pH} 10$ (b) on growth (closed symbols) and respiration activity (open symbols) of washed cells of strain $\mathrm{ACO}$. The $\mathrm{pH}$ buffering system was $0.1 \mathrm{M} \mathrm{HEPES} / \mathrm{NaHCO}_{3} /$ $\mathrm{NaCl}$ for the $\mathrm{pH}$ range from 6 to $8, \mathrm{NaHCO}_{3} / \mathrm{Na}_{2} \mathrm{CO}_{3}$ for the $\mathrm{pH}$ range 8.5-11.5 and $\mathrm{Na}_{2} \mathrm{CO}_{3} / \mathrm{NaOH}$ for $\mathrm{pH} 12$. Carboxydotrophic growth at salt content $2.5-3.5 \mathrm{M} \mathrm{Na}^{+}$was achieved after secondary inoculation from a culture adapted to $2 \mathrm{M} \mathrm{Na}^{+}$. Symbols: circles, carboxydotrophic growth and $\mathrm{CO}$ oxidation activity; triangles, heterotrophic growth with acetate and acetate oxidation activity; squares, sulfide oxidation activity.

respiration in contrast to acetate-grown cells. While the ability to oxidize sulfide is known for Alkalispirillum/Alkalilimnicola (Oremland et al., 2002; Sorokin et al., 2006b), the high level of formate-oxidizing activity in the CO-grown cells of all ACO strains is somewhat unexpected.

\section{Enzymic activity in cell fractions}

Four different enzyme activities were detected in the cellfree extract and its fractions obtained from the ACO1 cells grown with $\mathrm{CO}$. In the membrane fraction, $\mathrm{CODH}, \mathrm{FDH}$, SQR and cytochrome $c$ oxidase were detectable. In the soluble fraction, only $\mathrm{CODH}$ was present (Table 2). The $\mathrm{CODH}$ in membranes had a lower $\mathrm{pH}$ optimum than the $\mathrm{FDH}$, but both were only moderately alkalitolerant as compared with the whole-cell respiration, with $\mathrm{pH}$ optima at $8.5(\mathrm{CODH})$ and $9.0(\mathrm{FDH})$. This might be the result of either the intracellular localization of these two dehydrogenases (i.e. the internal side of the cell membrane) or an acidic shift in the $\mathrm{pH}$ profile of the enzymes under in vitro conditions with artificial electron acceptors.

Further evidence on the presence of two different enzyme systems responsible for the oxidation of $\mathrm{CO}$ and formate in ACO1 was obtained by comparing the protein expression of cells grown with different substrates and by in-gel activity staining (Fig. 5). Comparison of total cell extracts from the cells grown with $\mathrm{CO}$, formate and acetate identified two closely located polypeptide bands with apparent masses above $100 \mathrm{kDa}$ uniquely expressed during growth on CO (white arrows in Fig. 5a). Another band with a mass of $56 \mathrm{kDa}$ was present both in CO- and formate-grown cells but not in the acetate-grown cells (Fig. $5 a)$. Further comparison of different cell fractions demonstrated that the soluble fraction of the CO-grown cells contained only one high-molecular-mass band unique for $\mathrm{CO}$, while both of them were present in the membranes (Fig. 5b). Analysis of the membrane fraction also made it clear that the CO- and formate-grown cells shared two unique polypeptides with apparent masses of 56 and $15 \mathrm{kDa}$ (Fig. 5b). These observations led to the conclusion that the two high-molecular-mass bands with masses $>100 \mathrm{kDa}$, expressed in the CO-grown cells, belonged to a $\mathrm{CODH}$, while the 56 and $15 \mathrm{kDa}$ bands, present in the membranes of both CO- and formate-grown cells, belonged to an FDH. Activity staining of cell fractions from the CO-grown ACO1 cells (Fig. 5c) demonstrated the presence of two different high-molecular-mass complexes with $\mathrm{CODH}$ activity in soluble and membrane fractions, with apparently higher activity in the membranes, and a single FDH complex in the membranes. All three complexes had different molecular masses, indicating that the CODH and FDH are different enzymes in ACO1.

Overall, these data corresponded well to the results of activity measurements on the level of whole cells and in the cell-free extracts discussed above. On the other hand, the high molecular mass of the two polypeptide bands specific for CO-grown cells did not correspond to what is known for the classical CODH in other aerobic carboxydotrophs, which have a mass for the large catalytic $\alpha$-subunit in the range of $75-88 \mathrm{kDa}$. That the enzyme from ACO1 might differ from the classical CODH was also evident from the fact that the two primer pairs specific for the coxL gene in all known aerobic carboxydotrophs (King \& Weber, 2007) did not result in any amplification when the genomic DNA of ACO strains was used as a template. Attempts to vary the amplification conditions were not successful. 




Fig. 4. Respiration activity of washed cells of strain $\mathrm{ACO} 1$ grown at $\mathrm{pH} 10$ with different substrates. Data represent average values from two to three independent experiments.

\section{Cytochrome reduction in cell fractions of strain ACO1}

Addition of $\mathrm{CO}$ and formate to the whole-cell extract from ACO1 cells grown on $\mathrm{CO}$ resulted in a rapid reduction of cytochromes $c_{551}$ and $b_{557}$ (Supplementary Fig. S2). When the extract was separated into soluble and membrane fractions, only $\mathrm{CO}$ was able to act as a reductant for cytochromes. These results indicated that for both $\mathrm{CODH}$ and FDH, the initial accepting cytochromes were soluble. In contrast to the neutrophilic carboxydotrophs, the soluble cytochrome pool accepting electrons from the $\mathrm{CODH}$ in alkaliphilic strain ACO1 included cytochrome $c$. The fact that there was almost the same degree of reduction of soluble cytochromes with $\mathrm{CO}$ and ascorbate indicates that these cytochromes are high-potential $(\geqslant+100 \mathrm{mV})$. In the membranes, difference spectra showed the presence of two CO-reacting cytochromes, $b_{558}$ and $b_{562}$, which might be part of the cytochrome $c$ oxidase $c b b_{3}$. COdifference spectra showed the presence of a high concentration of soluble CO-binding cytochrome $b_{558}$, which most probably acts as a $\mathrm{CO}$ carrier.

Table 2. Enzymic activity in cell-free extracts from cells of ACO1 grown with $\mathrm{CO}$

\begin{tabular}{|lcccc|}
\hline Enzyme & $\mathbf{p H}$ & $\begin{array}{c}\mathrm{Na}^{+} \\
\text {concn }(\mathrm{M})\end{array}$ & \multicolumn{2}{c|}{$\begin{array}{c}\text { Activity } \\
(\mathbf{m g} \text { prot })^{-1}\end{array}$ min $\left.^{-1}\right]$} \\
\cline { 3 - 5 } & & & Membranes & $\begin{array}{r}\text { Soluble } \\
\text { fraction }\end{array}$ \\
\hline CODH & 8.5 & 0.5 & 1000 & 210 \\
FDH & $8.5-9.0$ & 0.5 & 560 & 0 \\
SQR & 9.5 & 0.3 & 20 & 0 \\
Cytochrome $c$ & 8.0 & 0.5 & 800 & 70 \\
oxidase & & & & \\
\hline
\end{tabular}

*Average from two independent sets of measurements.

\section{DISCUSSION}

This work has demonstrated that growth with $\mathrm{CO}$ as the electron donor is possible under extremely haloalkaline conditions and that carboxydotrophy under such extreme conditions is common among the facultatively autotrophic, haloalkaliphilic Gammaproteobacteria of the genera Alkalispirillum/Alkalilimnicola, which are characterized by a very versatile metabolism. Most probably, Alkalilimnicola ehrlichii, for which the potential to oxidize $\mathrm{CO}$ has been shown previously, is also capable of growth with $\mathrm{CO}$, but the conditions that allow such growth (oxygen and $\mathrm{CO}$ concentrations) remain to be determined. For the strains isolated in this study, carboxydotrophy was possible only at relatively low oxygen and $\mathrm{CO}$ concentrations.

An important question which remains unclear is the relevance of $\mathrm{CO}$ and its oxidation for soda lakes. This work was more focused on the study of pure cultures. However, there are two lines of evidence that indirectly indicate that $\mathrm{CO}$ oxidation in soda lakes might be important. One comes from the work with Alkalilimnicola ehrlichii, in which the potential to consume $\mathrm{CO}$ at p.p.m. concentrations has been demonstrated (Hoeft et al., 2007). Another is the indication of significant $\mathrm{CO}$ emission from hypersaline mats (Hoehler et al., 2001). Further environmental study is necessary to clarify the situation.

In general, the alkalispirilla are remarkably salt tolerant when grown heterotrophically; for example, with acetate. Surprisingly, the same was true for their carboxydotrophic growth. Among the known lithoautotrophs isolated from soda lakes, so far only sulfur-oxidizing members of the genus Thioalkalivibrio are capable of lithoautotrophic growth in saturated soda brines containing $4 \mathrm{M}$ total $\mathrm{Na}^{+}$(Sorokin et al., 2006a). Therefore, despite a very low growth rate with $\mathrm{CO}$, this energy source is equivalent to sulfide/thiosulfate in providing enough energy for bacteria to cope with extremely haloalkaline conditions. 




(a)

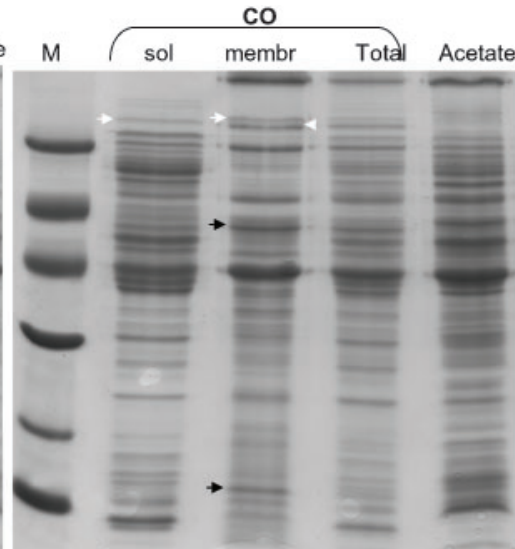

(b)



(c)

Fig. 5. Total protein profiles in cell fractions of strain ACO1 grown at $\mathrm{pH} 10$ with different substrates. (a) Comparison of total proteins expressed during growth with different substrates under denaturing conditions (5-20\% gradient); (b) comparison of total proteins in cell fractions from CO-grown cells under denaturing conditions (5-20\% gradient); (c) in-gel activity staining of $\mathrm{CODH}$ and $\mathrm{FDH}$ in cell fractions from the $\mathrm{CO}$-grown cells under non-denaturing conditions (7.5\%). Arrows and arrowheads indicate overexpressed polypeptides. Membrane preparations under non-denaturing conditions were solubilized with $0.1 \%$ ( $\mathrm{w} /$ v) $\beta$-D-dodecyl maltoside. Total protein loading was $30 \mu \mathrm{g}$ per lane. sol, Soluble fraction; membr, membrane fraction.

One of the most interesting physiological aspects of the carboxydotrophy in the novel isolates is the linking of the $\mathrm{CO}$ - and formate-oxidizing systems. The fact that both are expressed only during growth on $\mathrm{CO}$ might be interpreted in two ways: formate is either a co-substrate for the $\mathrm{CODH}$ or an intermediate of $\mathrm{CO}$ oxidation, and therefore growth with $\mathrm{CO}$ leads to the expression of FDH. The first possibility is not supported by the enzymic measurements that show the presence of two separate enzyme systems for $\mathrm{CO}$ and formate oxidation. We also could not find any evidence for formate accumulation during $\mathrm{CO}$ oxidation. So, at present, the reason for the triggering of high FDH activity in CO-grown cells of the alkalispirilla remains unclear.

As there is a rapid reduction of the soluble (periplasmic) cytochrome pool in the presence of $\mathrm{CO}$ and formate, the $\mathrm{CODH}$ and FDH must be exposed to the outside of the cell membrane. Together, the enzyme activity measurements, protein expression profiles and cytochrome reduction data suggest the schematic organization of the $\mathrm{CO} /$ formateoxidizing system in the alkaliphilic isolate ACO1 given in Fig. 6. CO reacts with the reduced soluble cytochrome $b_{558}$ in the periplasm and is transported to either a soluble or a membrane-bound $\mathrm{CODH}$, while formate reacts with a membrane FDH. Both dehydrogenases pass the electrons to the soluble periplasmic cytochrome $c_{552} /$ cytochrome $b_{557}$ complex, which finally delivers the electrons to the cytochrome $c$ oxidase, which may be of the $c b b_{3}$ type. Sulfide may be oxidized directly through a membranebound SQR.

Concluding, the ability to grow with $\mathrm{CO}$ under extremely haloalkaline conditions ( $\mathrm{pH}$ up to 10.4 and salt up to $3.5 \mathrm{M}$ total $\mathrm{Na}^{+}$) has been demonstrated for a group of Gammaproteobacteria belonging to the genera Alkalispirillum and Alkalilimnicola from hypersaline alkaline lakes. The carboxydotrophic growth occurs at relatively

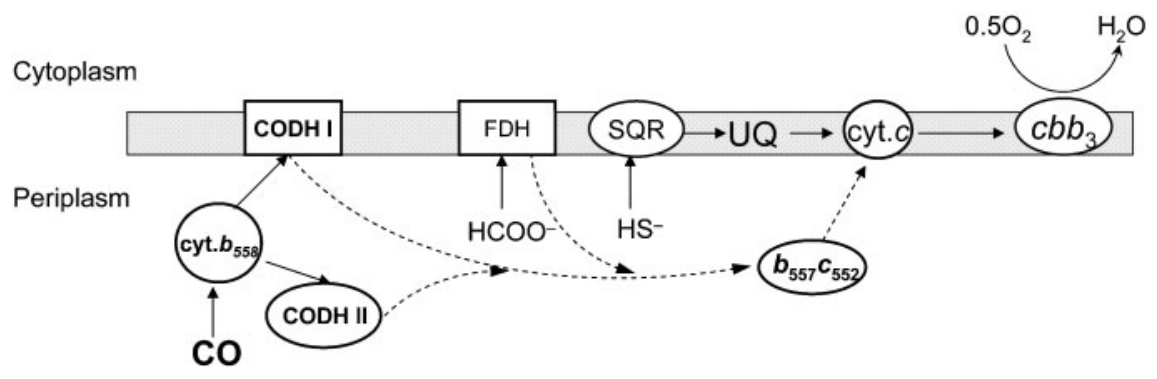

Fig. 6. Tentative scheme for inorganic substrate oxidation in haloalkaliphilic strain ACO1 based on enzyme activity measurements and cytochrome reduction data. cyt., Cytochrome. 
low oxygen and CO concentrations. The bacteria are facultative chemolithoautotrophs able to utilize CO (but not $\mathrm{H}_{2}$ ), formate and sulfide as electron donors, and presumably the Calvin-Benson cycle for inorganic carbon assimilation. The system of $\mathrm{CO}$ oxidation includes a soluble CO-binding cytochrome $b$, two different highmolecular-mass $\mathrm{CODH}$ complexes that donate electrons to a high-potential soluble cytochrome $b c$, and a membrane cytochrome $c$ oxidase, most probably of the $c b b_{3}$ type.

\section{ACKNOWLEDGEMENTS}

This work was supported by the Russian Foundation for Basic Research (RFBR) (grants 08-04-00005 and 10-04-00152). O. L. K. was supported by a FEMS Fellowship. We thank A. Lysenko for the total DNA analysis.

\section{REFERENCES}

De Ley, J., Caffon, H. \& Reinaerts, A. (1970). The quantitative measurement of DNA hybridization from renaturation rates. Eur $J$ Biochem 12, 133-140.

Dunfield, K. E. \& King, G. M. (2004). Molecular analysis of carbon monoxide-oxidizing bacteria associated with recent Hawaiian volcanic deposits. Appl Environ Microbiol 70, 4242-4248.

Hardy, K. R. \& King, G. M. (2001). Enrichment of high-affinity CO oxidizers in Maine forest soil. Appl Environ Microbiol 67, 3671-3676.

Hoeft, S. E., Switzer Blum, J., Stolz, J. F., Tabita, F. R., Witte, B., King, G. M., Santini, J. M. \& Oremland, R. S. (2007). Alkalilimnicola ehrlichii sp. nov., a novel arsenite-oxidizing, haloalkaliphilic gammaproteobacterium capable of chemoautotrophic or heterotrophic growth with nitrate or oxygen as the electron acceptor. Int J Syst Evol Microbiol 57, 504-512.

Hoehler, T. M., Bebout, B. M. \& Des Marais, D. J. (2001). The role of microbial mats in the production of reduced gases on the early Earth. Nature 412, 324-327.

King, G. M. (2003). Molecular and culture-based analyses of aerobic carbon monoxide oxidizer diversity. Appl Environ Microbiol 69, 72577265.

King, G. M. \& Weber, C. F. (2007). Distribution, diversity and ecology of aerobic CO-oxidizing bacteria. Nat Rev Microbiol 5, 107-118.

Laemmli, U. K. (1970). Cleavage of structural proteins during the assembly of the head of bacteriophage T4. Nature 227, 680-685.

Lorite, M. J., Tachil, J., Sanjua, J. N., Meyer, O. \& Berdmar, E. J. (2000). Carbon monoxide dehydrogenase activity in Bradyrhizobium japonicum. Appl Environ Microbiol 66, 1871-1876.

Lowry, O. H., Rosebrough, N. J., Farr, A. L. \& Randall, R. J. (1951). Protein measurement with Folin phenol reagent. J Biol Chem 193, 265-275.
Marmur, J. (1961). A procedure for the isolation of deoxyribonucleic acid from microorganisms. J Mol Biol 3, 208-218.

Marmur, J. \& Doty, P. (1962). Determination of the base composition of deoxyribonucleic acid from microorganisms. J Mol Biol 5, 109-118.

Meyer, O. \& Schlegel, H. G. (1978). Reisolation of the carbon monoxide utilizing hydrogen bacterium Pseudomonas carboxydovorans (Kistner) comb. nov. Arch Microbiol 118, 35-43.

Meyer, O., Frunzke, K., Gadkari, D., Jacobitz, S., Hugendieck, I. \& Kraut, M. (1990). Utilization of carbon monoxide by aerobes: recent advances. FEMS Microbiol Rev 87, 253-260.

Mörsdorf, G., Frunzke, K., Gadkari, D. \& Meyer, O. (1992). Microbial growth on carbon monoxide. Biodegradation 3, 61-82.

Oremland, R. S., Hoeft, S. E., Santini, J. M., Bano, N., Hollibaugh, R. A. \& Hollibaugh, J. T. (2002). Anaerobic oxidation of arsenite in Mono Lake water and by a facultative, arsenite-oxidizing chemoautotroph, strain MLHE-1. Appl Environ Microbiol 68, 4795-4802.

Pfennig, N. \& Lippert, K. D. (1966). Über das Vitamin $B_{12}$-bedürfnis phototropher Schwefelbacterien. Arch Microbiol 55, 245-256.

Schäfer, H. \& Muyzer, G. (2001). Denaturing gradient gel electrophoresis in marine microbial ecology. Methods Microbiol 30, 425-468.

Sorokin, D. Y. \& Kuenen, J. G. (2005). Alkaliphilic chemolithotrophs from soda lakes. FEMS Microbiol Ecol 52, 287-295.

Sorokin, D. Y., Banciu, H., Robertson, L. A. \& Kuenen, J. G. (2006a). Haloalkaliphilic sulfur-oxidizing bacteria. In: The Prokaryotes, Ecophysiology and Biochemistry, vol. 2, pp. 969-984. Edited by M. Dworkin, S. Falkow, E. Rosenberg, K. H. Schleifer \& E. Stackebrandt. New York: Springer.

Sorokin, D. Y., Zhilina, T. N., Lysenko, A. M., Tourova, T. P. \& Spiridonova, E. M. (2006b). Metabolic versatility of haloalkaliphilic bacteria from soda lakes belonging to the AlkalispirillumAlkalilimnicola group. Extremophiles 10, 213-220.

Spiridonova, E. M., Berg, I. A., Kolganova, T. V., Ivanovsky, R. N., Kuznetsov, B. B. \& Tourova, T. P. (2004). An oligonucleotide primer system for amplification of the ribulose-1,5-bisphosphate carboxylase/oxygenase genes of bacteria of various taxonomic groups. Microbiology 73, 316-325.

Tolli, J. D., Sievert, S. M. \& Taylor, C. D. (2006). Unexpected diversity of bacteria capable of carbon monoxide oxidation in a coastal marine environment, and contribution of the Roseobacter-associated clade to total CO oxidation. Appl Environ Microbiol 72, 1966-1973.

Tourova, T. P., Spiridonova, E. M., Berg, I. A., Slobodova, N. V., Boulygina, E. S. \& Sorokin, D. Y. (2007). Phylogeny and evolution of the family Ectothiorhodospiraceae based on comparison of 16S rRNA, $c b b L$ and nifH genes. Int J Syst Evol Microbiol 57, 2387-2398.

Van de Peer, Y. \& De Wachter, R. (1994). TREECON for Windows: a software package for the construction and drawing of evolutionary trees for the Microsoft Windows environment. Comput Appl Biosci 10, 569-570.

Edited by: H.-P. Klenk 